Отримано: 03.09.2019 р.

Прорецензовано: 11.09.2019 р.

Прийнято до друку: 17.09.2019 р.

e-mail: iryna.rybachok@oa.edu.ua

DOI: 10.25264/2409-6806-2019-28-47-55
Рибачок І. Основні напрями діяльності об’єднання українських жінок на еміграції (1945-1950). Наукові записки Начіонального університету «Ocmрозька академія». Серія «Історичні науки». Острог, 2019. Вип. 28. С. 47-55.

\title{
Ірина Рибачок
}

УДК 94(477). 153

\section{ОСНОВНІ НАПРЯМИ ДІЯЛЬНОСТІ ОБ'ЄДНАННЯ УКРАЇНСЬКИХ ЖІНОК НА ЕМІГРАЦІЇ (1945-1950)}

У статті проаналізовано головні вектори діяльності Об' 'єднання українських жінок на еміграиії (ОУЖ) - жіночої організаиії, щуо постала наприкіниі 1945 р. у Західній Німеччині, де перебувала значна кількість украӥнських переміщених осіб. 3 'ясовано, що украйнські жінки здійснили вагомий внесок у налагодження життя украӥнської громади в Ді-Пі таборах, активно займалися організаційною, культурно-освітньою, видавничою, господарською діяльністю, намагалися сприяти покращенню міжнародного іміджу украӥнців та актуалізовувати украӥнське питання після Другої світової війни.

Ключові слова: Ді-Пі табори, переміщені особи, українські жінки, Об'єднання украӥнських жінок на еміграиіiі.

\section{Iryna Rybachok}

\section{MAIN ACTIVITIES OF THE UKRAINIAN WOMEN'S UNION IN EMIGRATION (1945-1950)}

The article analyses main vectors of activity of the Ukrainian Women's Union in Emigration, a women's organization that emerged at the end of 1945 in West Germany, which housed a great number of Ukrainian displaced persons. Ukrainian women made a significant contribution to the life of the Ukrainian community in DP camps, actively engaged in organizational, cultural, educational, publishing, and business activities, tried to promote an international image of Ukrainians and to actualize the Ukrainian issue after World War II.

The membership and structure of the Ukrainian Women's Union in Emigration increased rapidly during 1945-1948. The Women's Union gradually eliminated its cells in a considerable number of camps after 1949, because the process of emigration of Ukrainian displaced persons to the permanent residential country became more intense.

Organized Ukrainian Women of West Germany, in cooperation with international women's and Ukrainian women's organizations overseas, sought to attract the attention of the world community to the issue of Soviet occupation of Ukraine, as well as to the forced repatriation of Ukrainian refugees from West Germany to the USSR after World War II, and emphasized the problem of refugee resettlement, especially regarding unfair restrictions on the least protected categories of displaced persons - widows, single mothers, orphans, disabled persons, the elderly, etc.

At the same time, important issues related to women's movement were left unaddressed by the Ukrainian Women's Union in Emigration. These were gender discrimination, women's rights and emancipation. These issues were not very relevant to ordinary women in difficult daily lives of displaced persons. Therefore, the main directions of the Ukrainian Women's Union in Emigration activities were aimed at improving daily life of Ukrainian displaced persons, protecting the rights and interests of the Ukrainian community, preserving national traditions, fighting for the restoration of the Ukrainian independent state, and creating a certain foundation for this in the form of nationally conscious youth. In order to accomplish these tasks, there were separate departments in the Ukrainian Women's Union in Emigration, which were responsible for organizational, publishing, economic, supportive, cultural and educational activities directions.

Key words: DP camps, displaced persons, Ukrainian women, Ukrainian Women's Union in Emigration.

Постановка проблеми. 3250 тис. українців, які опинилися після Другої світової війни в Австрії та Німеччині, близько третини становили жінки. Це жіноцтво мало різне соціальне походження, вік, жінки належали до різних релігійних конфесій, походили з різних регіонів України та за різних обставин потрапили до післявоєнної Європи. Деякі з них були вивезені на примусові роботи під час війни, інші - біженки з західноукраїнських земель чи радянської України, які були активними членами українських організацій чи підпільної боротьби. У важких умовах післявоєнного часу, залишивши 
свої домівки, рідних і Батьківщину, українські жінки у статусі біженок (переміщених осіб), а іноді і без нього, рятуючись від радянської репатріації, активно включилися в організацію таборового життя у післявоєнній Австрії та Західній Німеччині. Нові обставини проживання частково змінили «жіночий всесвіт», адже українська жінка, яка здавна вважалася берегинею роду, творцем домашнього затишку, господинею залишилася поза домом. Тимчасовими домівками для українських переміщених осіб найчастіше ставали приміщення колишніх німецьких військових казарм, таборів примусової праці, технічних шкіл, старих заводів, пожежних частин тощо. Житлові кімнати таборів були переповнені. Кількість біженців була такою, що ні вільних кімнат, ані вільних ліжок не було. У кімнатах проживало по 10-20 осіб. Люди намагалися знайти приватний куточок лише для себе, відмежовуючись стінами, зробленими з ковдри. В одній кімнаті могло мешкати кілька сімей, неодружених поселяли в окремі блоки, а отже в таких умовах жінка з берегині родини, перетворювалася на берегиню української громади.

Таборові умови двояко впливали на організацію українського жіноцтва, оскільки з однієї сторони вони вже мали досвід інституційного оформлення жіночого руху у вигляді діяльності Союзу Українок, діпістам у більшості випадків було притаманне почуття спільності та згуртованості українців, з іншої - перешкодою ставала слабка післявоєнна комунікація, побутові проблеми, невпевненість у майбутньому, відмінності у світогляді, особисті суперечки часто заважали створити потужну організаційну базу, яка б об'єднала українське жіноцтво в різних окупаційних зонах післявоєнної Австрії та Західної Німеччини.

Майже відразу з відкриттям таборів українки входили до таборових управ і творили жіночі відділи (секції), що займалися питаннями харчування, забезпечення, порядку, виховання та освіти дітей, дозвілля, опікувалися сиротами, вдовами, полоненими, інвалідами та людьми старшого віку в таборах. Майже у всіх таборах при управі існувала посада т.зв. жіночої референтки. Згодом ці жіночі осередки стали основою для творення українських жіночих об'єднань.

Процес інституційного становлення українського жіночого руху пришвидшила та обставина, що в післявоєнній Австрії та Західній Німеччині опинилася значна кількість активісток українських організацій Галичини та Закарпаття міжвоєнного періоду (зокрема «Союзу Українок», Пласту, ОУН), видатних діячок української культури, мистецтва, науки. Зокрема, Мілена Рудницька, Дарія Ребет, Марія Богачевська-Донцова, Ірина Павликовська, Марія Біляк, Уляна Целевич (Стецюк-Целевич, Дуда), Кекилія Гардецька (Цьопа Паліїв), Марія Химинець та ін. Із Надніпрянщини - Людмила Коваленко (Івченко), Віра Шпаківська, Олена Чехівська, Ізидора Косач-Борисова, Ольга Косач-Кривинюк, Слизавета Жук, Ганна Келлер-Чикаленко та ін.

Восени 1945 р. українські жінки в післявоєнній Австрії та Західній Німеччині створили дві жіночі організації: 1) Союз українок Свропи (СУЄ), який було започатковано на I жіночому з'їзді у Фельдкірху (Австрія), що відбувся 30 вересня і 1 жовтня 1945 р. $з$ ініціативи Мілени Рудницької) [45, p. 205]; 2) Об'єднання українських жінок на еміграції / Об'єднання українських жінок в Німеччині (далі - ОУЖ), яке засноване на I жіночому з’їзді в Авгсбурзі (Німеччина) 15-16 грудня 1945 р. 3 ініціативи Ірини Павликовської $[14 ; 16 ; 20 ; 19 ; 24]$. І. Павликовська, що також очолювала жіночий відділ Центрального Представництва Української Еміграції (далі - ЦПУЕН), мала підтримку Представництва на чолі з Василем Мудрим (ймовірно, в т.ч. через політичні погляди та партійну приналежність, адже В. Мудрий був лідером УНДО, як і Юліан Павликовський). Через низку конфліктів особистого та політичного характеру, що почалися ще в 30-х рр. XX ст. у Галичині і продовжилися у 40 -х рр. на еміграції [12, с. 131; 10, с. 12], цим двом лідеркам жіночого руху не вдалося знайти компроміс, а тому новопосталі жіночі організації в Ді-Пі таборах не змогли об'єднатися та налагодити співпрацю, а отже, можемо говорити про розкол в українському жіночому русі в цей період. СУЄ діяв у післявоєнній Австрії, частково у французькій зоні окупації Західної Німеччини, а після переїзду Мілени Рудницької у Швейцарію осередок перенесли до Женеви, натомість на теренах Західної Німеччини поширило свою діяльність ОУЖ, кількість членкинь якого стрімко зростала від кінця 1945 до 1949 рр.

Фрагментарні відомості про українське жіноцтво в Ді-Пі період представлені в загальних працях, присвячених переміщеним особам після Другої світової війни. Зокрема, в працях закордонних дослідників М. Ваймана [48], Г. Антонса [43; 44], Ю. Лаленде [47]; монографії українського діаспорного дослідника В. Маруняка [18], збірнику про українських Ді-Пі під редакцією В. Ісаєва та ін. [46]. Доробок сучасної української історіографії, присвячений феномену українських переміщених осіб 
після Другої світової війни, представлено працями С. Козака [16], О. Подобєд [27], Я. Рудика [30], Н. Сидоренко [32], Л. Стрільчук [34; 35], І. Тюрменко [39]. Безпосередньо діяльності ОУЖ присвячені ювілейні замітки членкинь організації - І. Козак [16], С. Нагірної [19], І. Павликовської [23; 24], О. Сулими [36]. Вперше науково обгрунтувала необхідність вивчення історії жінок у таборах ДіПі відома дослідниця українського жіночого руху М. Богачевська-Хом'як у своій статті «Жіночий рух в Ді-Пі таборах» [45], у якій серед іншого звернула увагу на розкол в українському жіночому русі в Ді-Пі період. Загалом, тема українського жіноцтва та його ролі у налагодженні життя української громади у Західній Німеччині після Другої світової війни є малодослідженою в українській історіографіі.

ОУЖ утворилося на першому з'їзді українського жіноцтва Західної Німеччини, що відбувся в Авгсбурзі (15-16 грудня 1945 р.), в якому взяли участь 48 українських жінок, що представляли 26 делегатур [24, с. 19]. На цьому з'їзді жінки виступали проти окупації України радянською владою; закликали українське жіноцтво в світі прийти на допомогу українським переміщеним особам; вирішили налагоджувати контакти з українськими організаціями за кордоном, а також із світовими жіночими організаціями, щоб поширювати правду про події на Україні $[24$, с. 20]. Пригадаймо, що навіть після завершення Другої світової війни на західноукраїнських теренах продовжував діяти національно-визвольний рух проти радянського режиму. Отже, завдання задекларовані на першому жіночому з'їзді чітко підкреслювали національно-громадську складову діяльності ОУЖ. Крім того, було вирішено чимало організаційних питань, а саме - визначили трирівневу будову організації (головна управа, обласні відділи, делегатури), окреслили завдання об'єднання, обрали керівні органи ОУЖ, зокрема Головну управу. До першого складу Головної управи ОУЖ увійшли Ірина Павликовська (голова), Марія Білякова й Олена Чехівська (заступники голови), Дора Рак (секретарка), Людмила Івченко (Коваленко) (пресова референтка), Віра Шпаківська (культурно-освітня референтка), Уляна Дида-Целевич (зв'язкова референтка), Стефанія Нагірна (фінансова референтка), Оксана Буревій (організаційна референтка), Кекелія Гардецька (господарська референтка), Анна Ганківська (референтка суспільної опіки)[24, с. 20-21; 1, арк. 13-14]. Всі члени управи були обрані з різних місцевостей американської зони, щоб краще підтримувати зв'язок і вирішувати поточні завдання. Проте, саме погана комунікація була важливою проблемою першого року діяльності ОУЖ. У зв'язку зі специфікою таборового періоду та родинними проблемами зі складу Головної управи в перший рік діяльності вийшли О. Буревій та Д. Рак. 3 перенесенням табору з Карлсфельду до Міттенвальду значно погіршилася, а з переїздом до Франкфурту припинилася праця референтки зв'язків У. Целевич, а з 1 лютого 1947 р. новою референткою зв'язків стала Дарія Ребет [1, арк. 14]. Загалом у 1947 р. було реорганізовано Головну управу, але не було організаційної референтки, тому ії обов'язки розділили I. Павликовська, Л. Івченко, В. Шпаківська, О. Чехівська, А. Гардецька. Саме цей напрямок роботи був дуже важливим в умовах становлення ОУж та налагодження діяльності жіночої організації у «таборовій Україні».

Організаційний напрямок праці ОУЖ був пов'язаний із розбудовою структури організації, налагодженням роботи між Головної управою, обласними відділами та делегатурами. У 1946 р. члени Головної управи здійснили 126 поїздок у делегатури для вирішення організаційних питань [1, арк. 14-15]. В умовах складної післявоєнної комунікації ці поїздки були досить важкими. Крім того, певною проблемою була і відсутність постійного осередку для Головної Управи ОУЖ. Спочатку централя ОУЖ знаходилася у спільному приміщенні з Відділом молоді ЦПУЕ у Мюнхені, з січня 1947 р. переїхали до Авгсбурга в приміщення ЦПУЕ [1, арк. 15-16] і тільки згодом ОУЖ викупило частину приміщення у Мюнхені.

Важливим організаційним завданням було проведення чотирьох жіночих з'їздів (в Авгсбурзі (1516 грудня 1945 р.), Ашаффенбурзі (29-30 березня 1947 р.), Штуттгарті (у вересні 1948 р.), Новому Ульмі (у березні 1950 р.)) [36, с. 47], підтримка зв'язку між Головною управою ОУЖ та діяльністю осередків ОУЖ у Західній Німеччині. Для інформування делегатур та посилення організаційного напряму роботи Головна управа видавала «Обіжники» та реферати (наприклад, М. Біляк «За правильну працю в делегатурах») [2, арк. 1]. Самі осередки ОУЖ швидко зростали від 1945 по 1948 рр. Так, у 1946 р. ОУЖ налічувала 53 делегатури, з них - 17 зосереджувалися в англійській зоні окупації Західної Німеччини, 2 - у французькій, 34 - в американській [4, с. 26-27]. Окремі з них були досить невеликими. Наприклад, делегатуру у Траунштайні на чолі з Оленою Кисілевською засновано у січні 1946 р., до якої напочатку входило 35 членок, вже через кілька місяців їх кількість подвоїлася 
(всього у таборі проживало 200 жінок) [3, с. 29]. Одним із важливих завдань було розширення діяльності організації та включення ширшого кола українок. У 1947 р. до складу ОУЖ входили вже 72 жіночі делегатури, з числом охопленого жіноцтва більше, як 7,500 членок [36, с. 47], 3’явилися нові обласні відділи у Вюртемберг-Бадені, Ашаффенбурзі, Ротенбурзі, Гесені [36, с. 48 ]. У 1948 р. кількість членок ОУЖ досягла 10 тис. осіб, проте значна частина жінок залишалася поза організацією. Управа ОУЖ прагнула популяризувати організацію і долучати до неї більше молодих жінок. Зауважимо, що протягом перших років у Ді-Пі таборах процес переселення не був досить інтенсивним, тому на постійні місця проживання виїжджала незначна кількість жінок, які і після переїзду підтримували контакти з Головною управою ОУЖ, займалися кольпортажем видань ОУЖ, допомагали матеріально або вже у «нових» країнах створювали жіночі осередки, або приєднувалися до вже існуючих українських жіночих організацій у цих країнах.

Рік 1949 р. став роком інтенсивного переселення українських переміщених осіб, близько 50\% українців виїхало із Західної Німеччини на постійні місця проживання. Це вплинуло на діяльність ОУЖ, іiі мережу та чисельність членок. Починається т.зв. ліквідаційний період у діяльності організації. У 1949 р. ліквідовано делегатури ОУЖ в Ашаффенбургу («Лягард» і «Піонір-Касерне»), Корнбергу, Вайсенбургу, Пфаркінхені, Райтерстайху, Міттенвальді («Піонір-Касерне»). 17 грудня 1949 р. на засіданні Головної управи ОУЖ було прийнято рішення про створення комісії у справі ліквідації делегатур у складі О. Чехівської, В. Шпаківської та О. Коломінської, які мали розглядати ліквідаційні звіти делегатур, а підсумки повідомляти Головній Управі [6, с. 11]. Так, 1950 р. залишилося 20 делегатур і значно зменшилася кількість членок.

У зв'язку з еміграцією українок у країни постійного проживання наприкінці 1940-х рр. часто змінювався склад управ осередків, в т.ч. і Головної Управи ОУЖ. Так, у 1949 р. зі складу Головної управи ОУЖ вибули такі членкині як Людмила Івченко, Марія Біляк (голова ОУЖ на англійську зону), Амалія Рублева (допомогова референтка), Ірина Бонковська (член Управи «Жіноча праця»), Стефанія Нагірна (організаційна референтка), Ірина Домбчевська, Кекелія Гардецька (членкиня управи 31945 р., господарська референтка і членкиня Управи кооперативи «Жіноча Праця», співробітниця «Громадянки»), І. Михайлів (членкиня ГУ), С. Карабай (секретарка ОУЖ від серпня до грудня 1949)), що емігрували до США [5, с. 10]. Голова ОУЖ Французької зони М. Солодуха 1949 р. емігрувала до Канади і у зв’язку з цим делегатури цієї зони були долучені під безпосереднє управління ОУЖ [6, с. 11]. У складі Головної управи у 1950 р. залишилися лише членкині, обрані Загальним 3’їздо: І. Павликовська, О. Чехівська, М. Бачинська-Донцова, В. Шпаківська, О. Павловська, Д. Ребет, Ів. Мірчук, а докооптовано - О. Коломінську (членкиня Обласної Управи ОУЖ) та І. Гинилевичеву [6, с. 11]. Вочевидь постали нові виклики, змінилися завдання ОУЖ і у зв’язку 3 цим було скликано Четвертий з’їзд ОУЖ на еміграції [22, с. 2].

До організаційного напряму можна віднести налагодження співпраці з жіночими організаціями за кордоном та іншими українськими організаціями, що діяли в Західній Німеччині. За інформування іноземних жіночих організацій про справи українських скитальців, налагодження співпраці 3 ними відповідала референтка зв'язку. У справі допомоги українській громаді, особливо таким категоріям як діти-сироти, вдови, самотні жінки, літні люди, ОУЖ співпрацювало з КОДУСом, ЦЕСУСом, СУМом, ЦПУЕН, Пластом, СХС, Червоним хрестом; з українськими жіночими організаціями за кордоном (СУА, КУК, СУК та ін.). Представниці ОУЖ зверталися до світових жіночих організацій у справі протесту проти радянської окупації України та проведення насильницької репатріації з Західної Німеччини до СРСР після Другої світової війни. У лютому 1946 р. написали лист Елеонорі Рузвельт про становище українських переміщених осіб [1, арк. 26].

Представниці ОУЖ брали участь у І Світовому конгресі українського жіноцтва, що відбувся 1213 листопада 1948 р. у Філадельфії, на якому було створено Світову федерацію українських жіночих організацій [31, с. 3]. Варто зазначити, що ОУЖ входило до десяти основоположних організацій, які заснували СФУЖО. На Перший світовий конгрес українського жіноцтва були запрошені І. Павликовська, Д. Ребет, Л. Івченко, М. Біляк, через проблеми з документами дві останні на конгрес не поїхали, тому під час конгресу у Філадельфії ОУЖ представляли І. Павликовська та Д. Ребет. Налагоджувалася співпраця з міжнародними жіночими осередками. У результаті співпраці з Світовим Об'єднанням Матерів (Mouvement Mondial des Meres) українські жінки надсилали свої вироби для виставок та благодійних продаж-базарів у Парижі 1949, 1950 pp. [8, с. 10]. 
ОУЖ намагалося налагодити контакти з іншими національними жіночими організаціями в Ді-Пі таборах. Наслідком було заснування Інтернаціональної жіночої ліги, у роботі якої брали участь і членкині ОУЖ.

Зважаючи на розкол в українському жіночому русі в період Ді-Пі, дуже цікавим є фрагмент звіту про співпрацю з українками, що опинилися у таборах для переміщених осіб в Австрії: «... В міру спромоги ми пересилаємо відомості про нашу працю до Союзу українок в Ляндеку і Інсбруку. Був час, коли вони навіть заявили охоту перемінити свою організацію на делегатуру ОУЖ, однак ми вважали це зайвим, бо без огляду на назву організації вони є для нас цінною організацією поскільки сповняють ті самі завдання, які ставимо перед собою і ми» [1, арк. 26].

Для налагодження контактів між жінками та жіночими осередками по таборах важливе значення мала видавнича діяльність ОУЖ. Так, Головна управа ОУЖ видавала журнал «Громадянка», який був друкованим органом жіночого об'єднання протягом 1946-1950 рр. Попри важкі умови еміграційного життя в журналі містилися різноманітні матеріали патріотичного, історичного, літературного, етнографічного, політичного характеру та низка практичних рубрик для жінок. Значна частина матеріалів часопису розкриває становище жіноцтва у Ді-Пі таборах та може служити важливим історичним джерелом до вивчення діяльності українок в Західній Німеччині після Другої світової війни. Так, матеріали журналу дають можливість розкрити інституційну будову ОУЖ, виділити основні напрями діяльності організації, простежити співпрацю ОУЖ з іншими українськими жіночими організаціями за кордоном, окреслити особливості таборового періоду крізь призму жіночого бачення. Крім «Громадянки», делегатури ОУЖ англійської зони видавали журнали для жінок «Українка» [40], делегатура у таборі Діллінген - журнал «Українка на чужині» [41], делегатура в Авгсбурзі «Українка у творах Шевченка». За редагування Лідії Гаєвської ОУЖ видавало дитячу газету «Сонечко» [33]. Видавництво «Молоде життя» у співпраці з Союзом українських пластунів та ОУЖ видавало місячник «Життя. Журнал української родини за кордоном» (Авгсбург, 1949).

Крім того, видавничо-пресовий відділ ОУЖ видавав обіжники, брошури, сценарії свят та реферати, присвячені самій організації та її завданням, видатним українським жінкам, різним історичним подіям. Ці реферати розсилали по таборах і читали під час жіночих зустрічей, свят чи при відзначенні різних роковин та ювілеїв. Крім того, розповсюджували матеріали 3 практичними порадами для жінок та матерів. Окремими книгами вийшли «Мала гігієна жінки», «Географічні нариси», «Взірці до вишивок» [42], різні дитячі збірники і казки для малечі. 3 метою просвітницької та культурно-освітньої діяльності розсилалися по таборах реферати на різні теми, виготовлялися монтажі для академій, свят, розповсюджувалася література з нарисами про українські звичаї, пісню, мистецтво тощо. В ОУЖ було створено фонд Лесі Українки, в який збирали гроші на видання творів письменниці англійською мовою.

Наприклад, реферати про українок: княгиню Ольгу, Олену Пчілку, Лесю Українку, Ольгу Кобилянську, Ольгу Басараб, Уляну Кравченко та ін. Так, 26 червня 1949 р. припало 100-річчя від народження Олени Пчілки, а делегатури ОУЖ відсвяткували цей ювілей читанням рефератів про ювілярку [11, с. 5]; 15 травня 1949 р. в Мюнхені відбулося свято Лесі Українки; 1949 р. в Берхтесгадені заходами ОУЖ була організована панахида та читання реферату для вшанування пам'яті Уляни Кравченко [25, с. 13]. Щорічно видавничо-пресова та культурно-освітня референтка організовували святкування у таборах для переміщених осіб Дня матері, Дня Св. Ольги (24 липня), яка була патронкою ОУЖ. Зазначимо, що ОУЖ також реалізовувало видання книг для жінок. Наприклад, на сторінках «Громадянки» містилася низка оголошень про можливість купівлі книг, інформація про нові видання для жінок, такі як «Мала гігієна жінки» Софії Парфанович, «Образ княгині Ольги» В. Дядинюк, «Крій і шиття» Іванни Дицьо-Мельник, «Географічні нариси» та ін. [42]

Культурно-освітній напрям роботи полягав у сприянні ОУЖ налагодженню системи виховання дітей, діяльності дитячих садочків, організації дитячих вистав та свят, приурочених різним подіям, проведення різних імпрез із залученням діячів культури та мистецтва, культивувалося національно-патріотичне виховання. ОУЖ вчиняло різноманітні культурні заходи для підняття рівня національної свідомості, вирішенні мовного питання (оскільки частина українських діпістів розмовляла російською). Загалом, особлива роль жінки розглядалася організацією у плеканні національної культури, традицій, в т.ч. шляхом виховання дітей. Для підняття інтелектуального та патріотичного рівня жіноцтва систематично делегатури ОУЖ влаштовували різноманітні вечори з читаннями рефератів, доповідями тощо. 
Важливим завданням ОУж було організовувати різноманітні навчально- виховні, розважальносвяткові заходи, гуртки для дітей, котрі проживали в Ді-Пі таборах. Наприклад, проведення свят зимового циклу: свята Миколая, Андрія, Маланки та ін. Під час яких влаштовувалися цікаві дитячі вистави, виконувалися пісні, танці. Для проведення подібних заходів Головна управа розсилала сценарії по делегатурах, а також ОУЖ у співпраці з іншими харитативними (благодійними) організаціями (СХС, КОДУС, ЗУАДК) шукало можливості для вручення дитячих подарунків [26, с. 7].

Таборові умови та невизначеність майбутнього стимулювали проводити фахову перекваліфікацію жінок з тим, щоб вони могли отримати спеціальність, що забезпечувала б добробут у країнах постійного проживання. 3 ініціативи ОУЖ було організовано та проведено низку фахових курсів для жінок. Зокрема, курси українознавства, англійської мови, вихователів у дитячі садки, крою та шиття, вишивання, мереження, куховарства, курс дрібної дитячої галантереї, санітарні курси («медична сестра»), машинописання, перукарства, виготовлення штучних квітів з різних матеріалів та ін. Навчання завершувалося мистецькою виставкою вишивок, народного одягу, ляльок та інших виробів курсанток. На основі цих матеріалів ОУЖ організовувало виставки українського народного мистецтва. Варто зазначити, що цей напрям діяльності ОУЖ був досить вдало й добре організованим. Можливо, цьому сприяло те, що І. Павликовська у міжвоєнний час очолювала кооперативу «Українське народне мистецтво» у Львові і мала досвід в організації подібних виставок, в т.ч. на міжнародному рівні. Цікаво, що окремі жінки вчилися на таборових курсах, що традиційно вважалися чоловічими. Так, в Корнберзі на шоферських курсах навчалося 5 жінок [38, с. 21].

Фахове навчання було також тісно пов'язане із господарським напрямом діяльності ОУЖ, що полягав у створенні різноманітних майстерень, у яких працювали жінки - кравецькі, з виготовлення вишивок, дитячих іграшок тощо. Головна управа ініціювала та заохочувала вступ жінок, особливо випускниць фахових курсів, у ці майстерні. Однак, у 1946 р. кількість бажаючих не була великою, оскільки цей рік українці у таборах мали досить добре забезпечення від УНРРА $[1$, арк. 30]. Робітниці майстерень отримували від таборової управи додаткове харчування та сигарети (які у повоєнних умовах можна було вигідно обміняти на що завгодно), 60-70\% вартості від оплати за роботу, а решта вартості надходила для централі кооперативи «Жіноча праця» та ОУЖ. Ці кошти спрямовувалися на забезпечення устаткуванням майстерень, на розвиток та потреби делегатур ОУЖ [1, арк. 31]. Під егідою ОУЖ діяла у повоєнній Німеччині кооператива «Жіноча праця» з головним осередком у Мюнхені $[15$, с. 7$]$. Жіночі майстерні були майже у всіх таборах, де жили українські переміщені особи. У них сотні українських жінок знаходили роботу, заробіток, отримували нові знання та навички у практичних галузях. Зауважимо, що праця у майстернях не лише допомагала українкам матеріально, а й мала важливе значення для морального піднесення чи була «відрадою» у часи важких особистих драм, які переживали українські жінки у таборах для переміщених осіб у Німеччині після Другої світової війни. У спогадах Ірини Ганушевської-Руснак міститься оповідь про те, як вона та ії родина переживали смерть своєї маленької донечки у Ді-Пі таборі (16-місячна Христинка «підхопила» хворобу від одного з сусідів по таборовій кімнаті, що хворів на відкриту форму туберкульозу): «... особливо жінки співчували мені - як мамі, що не могла натішитися своєю дитинкою, перейшовши такі тяжкі часи. Вони мене втягнули до Жіночої організації, не даючи сидіти в хаті та плакати. В мене вже й не ставало сил на плач. Знаходила спокій вишиваючи...» [7, с. 42-43].

Одним із найбільш затребуваних у таборових умовах був допомоговий напрям. Серед завдань ОУЖ було сприяння переселенню в країни постійного проживання тих категорій членів громади, в котрих не були зацікавлені заокеанські країни, зокрема йшлося про сиріт, вдів, хворих, інвалідів, людей похилого віку. ОУЖ протестувало проти доволі розрахункових форм переселення, багато разів зверталося до Міжнародної організації у справах біженців (International Refugee Organization - IPO) та інших організацій. Завдяки праці ОУЖ у цьому напрямку вже 1948 р. Великобританія дозволила переселення певного відсотку жінок з дітьми [13, с. 15]. Для вирішення проблеми переселення сиріт, одиноких жінок, хворих, людей похилого віку ОУЖ тісно співпрацювало з українськими жіночими організаціями Америки, Канади, Франції, Австрії, Англії, Бельгії, Італії, Швейцарії, Аргентини, Бразилії і Африки. Організовували різноманітні акції сприяння, складали списки сиріт і надсилали ïx до українських жіночих організацій у США і Канаду, які в свою чергу сприяли переселенню, допомагали харчами, одягом, грошима, різноманітними товарами. 3 метою допомоги в організації переселення одиноких матерів, сиріт, їх матеріальної підтримки у таборах було створено спеціальний фонд «Матері і дитини», до якого під час різноманітних заходів збирали кошти. 
Українське жіноцтво Західної Німеччини здійснювало чимало акцій у справі репрезентації та популяризації українства в світі, зокрема, шляхом співпраці з різними міжнародними організаціями, організації виставок українського народного мистецтва, публікації матеріалів про українське жіноцтво, українців, їх традиції, організації прийому іноземних гостей у таборах. Так, 9-20 листопада 1947 р. виставка українського народного мистецтва відбулася у Ганновері [37, с. 6]. Варто зазначити, що українське рукоділля, зокрема вишивка, високо цінувалося іноземцями. Вишиванки чи вишивані речі часто ставали подарунками для гостей табору, таборової адміністрації та ін. Наприклад, у 1947 р. ОУЖ надіслало британській принцесі Єлизаветі весільний дарунок. Зокрема скатертину і 12 серветок роботи мистецької вишивкарської майстерні в Мюнхені $[28$, с. 9]. Жіноцтво брало участь у антибільшовицьких демонстраціях, піднімало питання становища українських скитальців та насильницької репатріації, публікувало у періодичних виданнях матеріали про українську історію.

Водночас, важливі питання, пов'язані із жіночим рухом, залишилися поза увагою ОУЖ. Зокрема, йдеться про традиційні для жіночого руху питання дискримінації жінок, гендерну рівність, права жінок та емансипацію. Ймовірно, що ці питання були не надто актуальними для звичайних жінок у важкому повсякденні переміщених осіб. Основні напрями діяльності ОУЖ були спрямовані на покращення повсякдення українських переміщених осіб, захист прав та інтересів української громади, збереження національних традицій, боротьбу за відновлення української незалежної держави та створення певного фундаменту для цього у вигляді національно свідомої молоді, яку на чужині обов'язок навчити любити Батьківщину покладався на матір. Для реалізації цих завдань в ОУЖ діяли окремі відділи, які відповідали за організаційний, видавничий, господарський, допомоговий, культурно-освітній та просвітницький напрямок праці. Зазначимо, що ця хвиля еміграції (попри різний соціальний склад та обставини перебування в Західній Німеччині) вважала себе політичною еміграцією, тому жіночий рух був тісно пов'язаний із українською національною ідеєю.

\section{Список використаних джерел та літератури:}

1. Архів Українського вільного університету. Ф. ОУЖ. - II з'їзд ОУЖ. Секретарський звіт за працю Головної управи і Об'єднання українських жінок на еміграції, Арк. 13-32.

2. Архів Українського вільного університету. Ф. ОУЖ. - Обіжник. Ч. 6/47, травень 1947 р. 3 арк.

3. В емігрантських теренах. Громадянка, 1946, Ч. 1, С. $27-29$.

4. В Центральній управі нашого об'єднання. Громадянка, 1946, Ч. 1, С. 25-27.

5. Вісті з Централі. Громадянка. 1949. Ч. 5-6, С. 10.

6. Вісті з Централі. Громадянка. 1950. Ч. 1-3, С. 11.

7. Ганушевська-Руснак I. Спомини. Івано-Франківськ: Місто НВ, 2009, 116 с.

8. Гнатюк-Піснячевська А. Міжнародна виставка-продаж. Громадянка, 1950, Ч. 1-3, С. 10.

9. Голуб М. Делегатура ОУЖ в Регенсбурзі. Регенсбург. Статті. Спогади. Документи. До історії української еміграиії в Німеччині після Другої світової війни. Нью-Йорк; Париж; Сидней; Торонто, 1985. С. $420-423$.

10. Горохович Т. Український жіночий рух і СФУЖО. Промінь. 1977. Ч. 8-9. С. 11-13.

11. Доручення делегатурам ОУЖ. Громадянка. 1949. Р. IV, Ч. 5-6, С. 5.

12. Дядюк М. Український жіночий рух у міжвоєнній Галичині: між гендерною ідентичністю та національною заангажованістю. Львів: Астролябія, 2011. 368 с.

13. Жінки, на яких тяжить родина. Громадянка. 1948. Ч. 7-8. С. 15.

14. На громадській ниві (до 25 -ліття Центрального представництва української еміграції в Німеччині) / ред. О. Зеленецький. Мюнхен, 1972, С. 32.

15. І.Г. Дворіччя кооперативу «Жіноча праця». Господарсько-кооперативне життя. Місячний додаток до часопису «Наше життя». Авгсбург, 1947. Р. І, Ч. 5 (листопад), С. 7.

16. Козак I. Об’єднання українських жінок у Німеччині. 50-ліття СФУЖО. Ювілейна книга Світової Федерації Українських жіночих Організаиій (1948-1998) / М. Шпір. Торонто, 2002. С. 170-172.

17. Козак С. Проблема Ді-Пі в часописі «Українські вісті». Вісник Книжкової палати. 2013. № 11. С. 32-34.

18. Маруняк В. Українська еміграція в Німеччині і Австрії по Другій світовій війні. Т. 1. Роки 1945-1951. Мюнхен: Академічне вид-во д-ра Петра Белея, 1985. 429 с.

19. Нагірна С. Праця українського жіноцтва в Регенсбурзі - в оселі й області. Регенсбург. Статmі. Сnогади. Документи. До історії украӥнської еміграиії в Німеччині після Другої світової війни. Нью-Йорк; Париж; Сидней; Торонто, 1985. С. 393-419.

20. Об’єднання українських жінок на еміграції. Делегатура в Ельвангені. Один рік в таборі Ельванген. Ельванген, 1947, С. 49-51.

21. Павликовська Ірина. Енциклопедія українознавства / за ред. В. Кубійовича. Париж; Нью-Йорк: Видавництво «Молоде життя», 1966. Т. 5. С. 1917.

22. Павликовська I. 3 Новим Роком. Громадянка. 1950. Р. V. Ч. 1-3. С. 2.

23. Павликовська I. Об'єднання українських жінок на еміграції: його побудова і праця. Світовий конгрес українського жіноцтва: пам'яткова книжка. Філадельфія, 1948. 
24. Павликовська І. Об'єднання українських жінок у Німеччині. 35 років Об'єднання украӥнських жінок у Німеччині, 1945-1980. Мюнхен: ОУЖ, 1980, С. 13-28.

25. По наших делегатурах. Громадянка. 1949. Ч. 5-6. С. 12-13.

26. По наших делегатурах. Громадянка. 1950. Ч. 1-3. С. 7.

27. Подобєд О. Українська планета Ді-Пі: культура та повсякдення. Житомир: Видавництво О.О. Свенок, 2018,396 c.

28. Подяка Принцеси Слизавети. Громадянка, 1948. Ч. 9-10. С. 9.

29. Програма Світового конгресу українського жіноцтва 12 і 13 листопада в готелі Аделфія. Наше життя. 1948, Ч. 11. С. 5.

30. Рудик С.Я. Переселення українських біженців і переміщених осіб до США та Канади після Другої світової війни: причини, особливості, наслідки (1945-1953 рр.): автореф. дис... канд. іст. наук. К., 2003.20 с.

31. Світовий конгрес українського жіноцтва. Громадянка, 1948, Ч. 9-10, С. 3-6.

32. Сидоренко Н.М. Журналістська «Планета Ді-Пі»: Українська преса у таборах військовополонених, переміщених осіб і біженців у Свропі після II Світової війни (1945-1950). Київ: Дослідницький центр історії укр. преси, 2000. 175 с.

33. Сонечко. Газета для малят. 1947, № 1-2 (травень).

34. Стрільчук Л. Просвітницька діяльність української інтелігенції в таборах для переміщених осіб у західних окупаційних зонах (1944-1951 pp.). Науковий вісник Східноєвропейського національного університету імені Лесі Українки. 2016. № 3. С. 69-74.

35. Стрільчук Л.В. Українські політичні біженці та переміщені особи після Другої світової війни: автореф. дис... канд. іст. наук. Чернівці, 1999. 16 с.

36. Сулима О. Об’єднання українських жінок Німеччини. Українка у Вільному світі. Збірник, виданий у 75-ліття українського жіночого руху і 10-ліття Світової федерації українських жіночих організацій. Нью-Йорк, 1959. C. 47-51.

37. Третій з’їзд Об’єднання українських жінок на еміграції. Наше життя.1948, Ч.11. С. 6.

38. Трофімовська О. Одна $з$ делегатур. Громадянка, 1946, Ч. 3. С. 19-22.

39. Тюрменко І. Документальна україніка про становище українських переміщених осіб у повоєнній Європі (1945-1957). Емінак: науковий щоквартальник. 2018. № 3 (23) (липень-вересень). Т. 2. С. 51-57.

40. Українка. Ганновер, 1946. Ч. 1 (січень).

41. Українка на чужині. Таборовий часопис Об’єднання українських жінок. Делегатура Діллінген. 1948, Ч. 1.

42. Цікаві для нас видання. Громадянка, 1947, Ч. 5. С. 8.

43. Antons, J.-H. Das «Ausländerlager» Heidenau. Ukrainische Displaced Persons in der Nordheide. Kreiskalender 2009. Jahrbuch für den Landkreis Harburg, Winsen 2008, P. 97-108.

44. Antons J.-H. Displaced Persons in Postwar Germany: Parallel Societies in a Hostile Environment. Journal of Contemporary History, 2014, Vol. 49 (I). P. 92-114.

45. Bohachevsky-Chomiak M. The Women's Movement in the DP Camps. The Refugee Experience: Ukrainian Displaced Persons after World War II / ed. Isajiw W., Boshyk Y., Senkus R. Edmonton: CIUS, 1992, P. $201-219$. 46. The Refugee Experience: Ukrainian Displaced Persons after World War II. Edmonton : CIUS, 518 p.

47. Lalande, J. «Building a Home Abroad» - A Comparative Study of Ukrainian Migration, Immigration Policy and Diaspora Formation in Canada and Germany after the Second World War. Toronto, 2006, $458 \mathrm{p}$.

48. Wyman, M., 1989, DP Europe's Displaced Persons, 1945-1951. Philadelphia; London; Toronto, 257 p.

\section{References}

1. Arkhiv Ukrainskoho vilnoho universytetu. F. OUZh. - II zizd OUZh. Sekretarskyi zvit za pratsiu Holovnoi upravy i Obiednannia ukrainskykh zhinok na emihratsii, Ark. 13-32.

2. Arkhiv Ukrainskoho vilnoho universytetu. F. OUZh. - Obizhnyk. Ch. 6/47, traven 1947 r. 3 ark.

3. V emihrantskykh terenakh. Hromadianka, 1946, Ch. 1, S. 27-29.

4. V Tsentralnii upravi nashoho obiednannia. Hromadianka, 1946, Ch. 1, S. 25-27.

5. Visti z Tsentrali. Hromadianka. 1949. Ch. 5-6, S. 10.

6. Visti z Tsentrali. Hromadianka. 1950. Ch. 1-3, S. 11.

7. Hanushevska-Rusnak I. Spomyny. Ivano-Frankivsk: Misto NV, 2009, 116 s.

8. Hnatiuk-Pisniachevska A. Mizhnarodna vystavka-prodazh. Hromadianka, 1950, Ch. 1-3, S. 10.

9. Holub M. Delehatura OUZh v Regensburzi. Regensburh. Statti. Spohady. Dokumenty. Do istorii ukrainskoi emihratsii v Nimechchyni pislia Druhoi svitovoi viiny. Niu-York; Paryzh; Sydnei; Toronto, 1985. S. 420-423.

10. Horokhovych T. Ukrainskyi zhinochyi rukh i SFUZhO. Promin. 1977. Ch. 8-9. S. 11-13.

11. Doruchennia delehaturam OUZh. Hromadianka. 1949. R. IV, Ch. 5-6, S. 5.

12. Diadiuk M. Ukrainskyi zhinochyi rukh u mizhvoiennii Halychyni: mizh hendernoiu identychnistiu ta natsionalnoiu zaanhazhovanistiu. Lviv: Astroliabiia, 2011. $368 \mathrm{s.}$

13. Zhinky, na yakykh tiazhyt rodyna. Hromadianka. 1948. Ch. 7-8. S. 15.

14. Na hromadskii nyvi (do 25-littia Tsentralnoho predstavnytstva ukrainskoi emihratsii v Nimechchyni) / red. O. Zelenetskyi. Miunkhen, 1972, S. 32.

15. I.H. Dvorichchia kooperatyvu «Zhinocha pratsia». Hospodarsko-kooperatyvne zhyttia. Misiachnyi dodatok do chasopysu «Nashe zhyttia». Avgsburg, 1947. R. I, Ch. 5 (lystopad), S. 7.

16. Kozak I. Obiednannia ukrainskykh zhinok u Nimechchyni. 50-littia SFUZhO. Yuvileina knyha Svitovoi Federatsii Ukrainskykh zhinochykh Orhanizatsii (1948-1998) / M. Shpir. Toronto, 2002. S. 170-172.

17. Kozak S. Problema Di-Pi v chasopysi «Ukrainski visti». Visnyk Knyzhkovoi palaty. 2013. № 11. S. 32-34. 
18. Maruniak V. Ukrainska emihratsiia v Nimechchyni i Avstrii po Druhii svitovii viini. T. 1. Roky $1945-1951$. Miunkhen: Akademichne vyd-vo d-ra Petra Beleia, 1985. 429 s.

19. Nahirna S. Pratsia ukrainskoho zhinotstva v Regensburzi - v oseli y oblasti. Regensburh. Statti. Spohady. Dokumenty. Do istorii ukrainskoi emihratsii v Nimechchyni pislia Druhoi svitovoi viiny. Niu-York; Paryzh; Sydnei; Toronto, 1985. S. 393-419.

20. Obiednannia ukrainskykh zhinok na emihratsii. Delehatura v Elvanheni. Odyn rik v tabori Elvangen. Elvangen, 1947, S. 49-51.

21. Pavlykovska Iryna. Entsyklopediia ukrainoznavstva / za red. V. Kubiiovycha. Paryzh; Niu-York: Vydavnytstvo «Molode zhyttia», 1966. T. 5. S. 1917.

22. Pavlykovska I. Z Novym Rokom. Hromadianka. 1950. R. V. Ch. 1-3. S. 2.

23. Pavlykovska I. Obiednannia ukrainskykh zhinok na emihratsii: yoho pobudova i pratsia. Svitovyi konhres ukrainskoho zhinotstva: pamiatkova knyzhka. Filadelfiia, 1948.

24. Pavlykovska I. Obiednannia ukrainskykh zhinok u Nimechchyni. 35 rokiv Obiednannia ukrainskykh zhinok u Nimechchyni, 1945-1980. Miunkhen: OUZh, 1980, S. 13-28.

25. Po nashykh delehaturakh. Hromadianka. 1949. Ch. 5-6. S. 12-13.

26. Po nashykh delehaturakh. Hromadianka. 1950. Ch. 1-3. S. 7.

27. Podobied O. Ukrainska planeta Di-Pi: kultura ta povsiakdennia. Zhytomyr: Vydavnytstvo O.O. Yevenok, 2018, $396 \mathrm{~s}$.

28. Podiaka Pryntsesy Yelyzavety. Hromadianka, 1948. Ch. 9-10. S. 9.

29. Prohrama Svitovoho konhresu ukrainskoho zhinotstva 12 i 13 lystopada v hoteli Adelfiia. Nashe zhyttia. 1948, Ch. 11. S. 5.

30. Rudyk S.Ia. Pereselennia ukrainskykh bizhentsiv i peremishchenykh osib do SShA ta Kanady pislia Druhoi svitovoi viiny: prychyny, osoblyvosti, naslidky (1945-1953 rr.): avtoref. dys... kand. ist. nauk. K., 2003.20 s.

31. Svitovyi konhres ukrainskoho zhinotstva. Hromadianka, 1948, Ch. 9-10, S. 3-6.

32. Sydorenko N.M. Zhurnalistska «Planeta Di-Pi»: Ukrainska presa u taborakh viiskovopolonenykh, peremishchenykh osib i bizhentsiv u Yevropi pislia II Svitovoi viiny (1945-1950). Kyiv: Doslidnytskyi tsentr istorii ukr. presy, 2000. $175 \mathrm{~s}$.

33. Sonechko. Hazeta dlia maliat. 1947, № 1-2 (traven).

34. Strilchuk L. Prosvitnytska diialnist ukrainskoi intelihentsii v taborakh dlia peremishchenykh osib u zakhidnykh okupatsiinykh zonakh (1944-1951 rr.). Naukovyi visnyk Skhidnoievropeiskoho natsionalnoho universytetu imeni Lesi Ukrainky. 2016. № 3. S. 69-74.

35. Strilchuk L.V. Ukrainski politychni bizhentsi ta peremishcheni osoby pislia Druhoi svitovoi viiny: avtoref. dys... kand. ist. nauk. Chernivtsi, 1999. $16 \mathrm{~s}$.

36. Sulyma O. Obiednannia ukrainskykh zhinok Nimechchyny. Ukrainka u Vilnomu sviti. Zbirnyk, vydanyi u 75-littia ukrainskoho zhinochoho rukhu i 10-littia Svitovoi federatsii ukrainskykh zhinochykh orhanizatsii. Niu-York, 1959. S. 47-51.

37. Tretii zizd Obiednannia ukrainskykh zhinok na emihratsii. Nashe zhyttia.1948, Ch.11. S. 6.

38. Trofimovska O. Odna z delehatur. Hromadianka, 1946, Ch. 3. S. 19-22.

39. Tiurmenko I. Dokumentalna ukrainika pro ctanovyshche ukrainskykh peremishchenykh osib u povoiennii Yevropi (1945-1957). Eminak: naukovyi shchokvartalnyk. 2018. № 3 (23) (lypen-veresen). T. 2. S. 51-57.

40. Ukrainka. Hannover, 1946. Ch. 1 (sichen).

41. Ukrainka na chuzhyni. Taborovyi chasopys Obiednannia ukrainskykh zhinok. Delehatura Dillinhen. 1948, Ch. 1 .

42. Tsikavi dlia nas vydannia. Hromadianka, 1947, Ch. 5. S. 8.

43. Antons, J.-H. Das «Ausländerlager» Heidenau. Ukrainische Displaced Persons in der Nordheide. Kreiskalender 2009. Jahrbuch für den Landkreis Harburg, Winsen 2008, P. 97-108.

44. Antons J.-H. Displaced Persons in Postwar Germany: Parallel Societies in a Hostile Environment. Journal of Contemporary History, 2014, Vol. 49 (I). P. 92-114.

45. Bohachevsky-Chomiak M. The Women's Movement in the DP Camps. The Refugee Experience: Ukrainian

Displaced Persons after World War II / ed. Isajiw W., Boshyk Y., Senkus R. Edmonton: CIUS, 1992, P. $201-219$.

46. The Refugee Experience: Ukrainian Displaced Persons after World War II. Edmonton : CIUS, 518 p.

47. Lalande, J. «Building a Home Abroad» - A Comparative Study of Ukrainian Migration, Immigration Policy and Diaspora Formation in Canada and Germany after the Second World War. Toronto, 2006, $458 \mathrm{p}$.

48. Wyman, M., 1989, DP Europe's Displaced Persons, 1945-1951. Philadelphia; London; Toronto, 257 p. 